\title{
USE OF AN EXPERIMENTAL AUTOIMMUNE MODEL TO DEFINE NERVE GROWTH FACTOR DEPENDENCY OF PERIPHERAL AND CENTRAL SUBSTANCE P-CONTAINING NEURONS IN THE RAT ${ }^{1}$
}

\author{
MAUREEN ROSS,, 2 SONJA LÖFSTRANDH, ${ }^{*}$ PAMELA D. GORIN,,${ }^{3}$ EUGENE M. JOHNSON, $\ddagger$ AND \\ JOAN P. SCHWARTZ*,4 \\ ${ }^{*}$ Laboratory of Preclinical Pharmacology, National Institute of Mental Health, Saint Elizabeth's Hospital, Washington, DC 20032 and \\ $\ddagger$ Department of Pharmacology, Washington University Medical School, St. Louis, Missouri 63110
}

\begin{abstract}
Rats exposed to maternal antibodies against nerve growth factor (NGF) in utero and in milk have been used to investigate the developmental dependency of various substance $P$-containing neurons on NGF. Substance $P$ and other peptides were measured by radioimmunoassays. The substance $P$ content of sensory ganglia, spinal cord, and skin was depleted 40 to $60 \%$ in anti-NGF-treated rats. These results demonstrate the NGF dependence of substance P-containing neurons in sensory ganglia. Opiate binding in the spinal cord was not changed despite the large depletion in substance P: the $B_{\max }$ and $K_{D}$ were the same in control and treated animals. The results suggest that opiate receptors may not be located presynaptically on substance P-containing primary afferents. Among the peripheral tissues which were assayed (ileum, submaxillary gland, retina, and adrenal), substance $P$ decreased only in the adrenal, suggesting innervation by a NGF-dependent substance P-containing neuron. No changes were detected in the substance $P$ content of nine different brain regions, in agreement with previous observations on the lack of effect of NGF on central neurons.
\end{abstract}

Recently, it has become possible to ascertain the physiological role of nerve growth factor (NGF) ${ }^{5}$ in vivo, both prenatally and postnatally, by the use of an experimental autoimmune model of NGF deprivation (Gorin and Johnson, 1979; Johnson et al., 1980). Adult rats or guinea pigs that are immunized with NGF are found to produce antiNGF antibodies which are transferable in utero to the fetus and in milk to the neonate. This approach facilitates reassessment of the role of NGF in the development of various neurons of the central and peripheral nervous system, a role which heretofore has been defined indirectly by the effect of NGF on embryonic tissues in vitro

\footnotetext{
'This work was supported by the March of Dimes and by National Institutes of Health Grant HL20604. We gratefully acknowledge the help of Pat Osborne and Peter DiStefano. E. M. J. is an established investigator of the American Heart Association.

${ }^{2}$ Present address: Children's Hospital of San Francisco, 3700 California St., San Francisco, CA 94118.

${ }^{3}$ Present address: Department of Physiology, University of California, San Francisco, CA 94143.

${ }^{4}$ To whom correspondence should be addressed at Laboratory of Preclinical Pharmacology, National Institute of Mental Health, Saint Elizabeth's Hospital, Washington, DC 20032.

${ }^{5}$ The abbreviations used are: BSA, bovine serum albumin; DRG, dorsal root ganglia; ECDI, 1-ethyl-3-(3-dimethylaminopropyl)carbodiimide; Met, methionine; NGF, nerve growth factor; SP, substance P; Tris, tris(hydroxymethyl)aminomethane; Tyr, tyrosine.
}

or by the effects of heterologous anti-NGF antiserum in vivo (Levi-Montalcini and Angeletti, 1968; Levi-Montalcini and Booker, 1960).

The autoimmune approach has provided additional evidence for the requirement for NGF in the development of immature sympathetic neurons (Gorin and Johnson, 1979) and has provided data which indicate that NGF is required for the maintenance of mature sympathetic neurons (Gorin and Johnson, 1980). Moreover, anti-NGF antibodies have been shown to have a deleterious effect on the development of sensory neurons (Johnson et al., 1980). In rats, in utero exposure to antiNGF antiserum results in a 70\% decrease in neuronal cell number in dorsal root ganglia (DRG). The ability of sensory neurons to transport ${ }^{125} \mathrm{I}-\mathrm{NGF}$ retrogradely (Stoeckel et al., 1975; Gorin and Johnson, 1979) is similarly impaired. Sensory neurons are comprised of a variety of cell types (Andres, 1961). As yet, no neurochemical markers have been studied in association with the lesions in sensory ganglia associated with NGF deprivation in utero. In tissue culture, however, the substance $P$ (SP) content of chick embryo DRG neurons is regulated by NGF (Schwartz and Costa, 1979). Furthermore, NGF has been shown to affect the development of SP-containing neurons in the sensory ganglia of the newborn animal (Kessler and Black, 1980; Otten et al., 1980).

SP is an undecapeptide which has been postulated to 
serve as a neurotransmitter both in the central (Otsuka and Konishi, 1975; Henry, 1976) and peripheral nervous system (Katayama et al., 1979; Morita et al., 1980). In particular, it has been suggested that SP functions as a neurotransmitter in certain primary afferents involved in the transmission of pain (Henry, 1976; Randic and Miletic, 1977). Immunohistochemistry confirms the presence of this peptide in neuronal perikarya of DRG and in the small diameter $\mathrm{C}$ fibers projecting to the skin and spinal cord (Chan-Palay and Palay, 1977a, b; Hokfelt et al., 1977). SP is released from the spinal cord in vivo by the activation of nociceptive sensory afferents, a release which is inhibited by opiates (Yaksh et al., 1980).

In the experiments reported here, rats exposed to antiNGF antiserum in utero and in milk have been used to investigate further the effects of NGF deprivation on sensory ganglia. An attempt has been made to correlate previously observed changes in cell number and protein content with a specific biochemical alteration in a subpopulation of DRG neurons containing SP. In addition, the sensitivity of other SP-containing neurons to NGF has been determined and the effects of NGF deprivation on opiate receptors in the spinal cord is reported.

\section{Materials and Methods}

\section{Substance $P$ radioimmunoassay}

Peptide conjugation. SP (Peninsula Laboratories, San Carlos, CA) was coupled to bovine serum albumin (BSA, Sigma Chemical Co., St. Louis, MO) with 1-ethyl-3-(3dimethylaminopropyl)carbodi-imide (ECDI, Sigma) using a molar ratio of peptide:BSA:ECDI of 50:1:560 (Goodfriend et al., 1964). Conjugation was allowed to proceed at room temperature for $20 \mathrm{hr}$ prior to the removal of unreacted SP by dialysis against saline at $4^{\circ} \mathrm{C}$ for $48 \mathrm{hr}$. Efficiency of coupling, as monitored by the inclusion of ${ }^{125} \mathrm{I}-\mathrm{Tyr}^{8}-\mathrm{SP}$ in the reaction mixture, was typically $40 \%$.

Immunization. The BSA conjugate of SP in isotonic saline was emulsified with an equal volume of Freund's complete adjuvant (Calbiochem, La Jolla, CA). Approximately $200 \mu \mathrm{g}$ of the conjugated peptide were injected intradermally at 30 sites on the shaved back of a New Zealand white rabbit. Booster injections using one-half of the initial dose of the immunogen were given at 3- to 4 -week intervals. The rabbit was bled 10 to 14 days following the booster dose. SP antibody obtained by this protocol was usable at a final dilution of $1: 20,000$ with $30 \%$ of the added radiolabeled peptide bound to the antibody in the absence of competing ligand.

Iodination of SP. $\mathrm{Tyr}^{8}$-SP (Peninsula Laboratories, San Carlos, CA) was labeled with ${ }^{125}$ I (Amersham Corp., Arlington Heights, IL) using a modification of the procedure of Hunter and Greenwood (1962). Typically, 2 $\mathrm{mCi}$ of $\mathrm{Na}^{125} \mathrm{I}$ was reacted with an equimolar amount of $\mathrm{Tyr}^{8}-\mathrm{SP}$ in the presence of $10 \mu \mathrm{g}$ of chloramine $\mathrm{T}$ (Eastman, Rochester, NY) in a total reaction volume of $70 \mu \mathrm{l}$. After $25 \mathrm{sec}$ at room temperature, the reaction was terminated by the addition of $100 \mu \mathrm{g}$ of sodium metabisulfite (Fisher Scientific Co.). All reagents were prepared in $100 \mathrm{~mm}$ sodium phosphate buffer, $\mathrm{pH}$ 7.4. Unreacted peptide was separated from ${ }^{125} \mathrm{I}-\mathrm{Tyr}^{8}$-SP by gel filtration on Sephadex G-10 $(24 \times 1.2 \mathrm{~cm})$ eluted with $50 \mathrm{~mm}$ trifluoroacetic acid containing $0.1 \%$ Triton X-100.
Radioimmunoassay incubation conditions. Test substances or standards $(100 \mu \mathrm{l})$, dissolved in $100 \mathrm{~mm}$ sodium phosphate buffer, pH 7.4, containing $10 \%$ BSA, were incubated for a minimum of $2 \mathrm{hr}$ at $4^{\circ} \mathrm{C}$ with $100 \mu \mathrm{l}$ of SP antibody diluted in sodium phosphate buffer, $\mathrm{pH} 7.4$, containing $0.1 \%$ BSA. Subsequently, $100 \mu \mathrm{l}$ of ${ }^{125} \mathrm{I}^{-\mathrm{Tyr}^{8}-}$ SP $(5,000$ to $7,000 \mathrm{cpm})$ were added and the incubation continued overnight at $4^{\circ} \mathrm{C}$. Antibody-bound SP was separated from free peptide at $4^{\circ} \mathrm{C}$ by the addition of 1 $\mathrm{ml}$ of a charcoal slurry containing $10 \mathrm{mg}$ of charcoal, 1 $\mathrm{mg}$ of dextran, and $10 \mathrm{mg}$ of BSA. After centrifugation $(4,800 \times g, 10 \mathrm{~min})$, the radioactivity bound to the antibody was determined by counting an aliquot of the supernatant. Test substances or standards giving less than $15 \%$ or more than $85 \%$ inhibition of control binding were excluded from the data analysis. Control binding is defined as the binding of ${ }^{125} \mathrm{I}-\mathrm{Tyr}^{8}$-SP to the antibody in the absence of competing ligand. Cross-reactivity is defined as 100 times the ratio of the $\mathrm{IC}_{50}$ (molar concentration required to inhibit $50 \%$ of the antibody binding of radiolabeled peptide) of $\mathrm{SP}$ to the $\mathrm{IC}_{50}$ of the test peptide. All test peptides (Peninsula Laboratories) used in crossreactivity studies were assayed in triplicate at a minimum of six concentrations.

Preparation of tissue extracts. SP, somatostatin, and methionine-enkephalin (Met-enkephalin) were extracted from rat tissues by a modification of the procedure of Chang and Leeman (1970). Tissues were homogenized in 100:3 (v:v) acetone:1 $\mathrm{N} \mathrm{HCl}$ and extracted on ice for $2 \mathrm{hr}$ prior to centrifugation at $17,000 \times g$ for $20 \mathrm{~min}$. The resultant supernatant was saved and the pellet was reextracted with 80:20 (v:v) acetone:0.01 N HCl. After 20 min on ice, samples were centrifuged as above, the supernatant was saved, and the pellet was dissolved in $1 \mathrm{~N}$ $\mathrm{NaOH}$ for protein determination. The combined supernatants were extracted three times with one-third of their combined volume of petroleum ether. The residual aqueous layer was frozen, lyophilized, and stored at $-70^{\circ} \mathrm{C}$ prior to assay. Recovery experiments using ${ }^{125} \mathrm{I}$ $\mathrm{Tyr}^{8}$-SP, ${ }^{125} \mathrm{I}$-Tyr ${ }^{1}$-somatostatin (New England Nuclear, Boston, MA), or $\left[{ }^{3} \mathrm{H}\right]$ Met-enkephalin (New England Nuclear, Boston, MA) indicated an overall efficiency of recovery of $89.5 \%, 88.5 \%$, or $80.9 \%$, respectively. For assay, tissue extracts were reconstituted in $100 \mathrm{~mm}$ sodium phosphate buffer, pH 7.4, containing $10 \%$ BSA. The levels of peptides in tissue extracts reported here actually refer to levels of SP-, somatostatin-, or Met-enkephalinlike immunoreactivity.

Nerve growth factor (NGF) was extracted from rat submaxillary glands as previously described (Schwartz and Costa, 1977).

Radioimmunoassays for somaloslatin, Met-enkephalin, and $\beta-N G F$. Immunoassays for somatostatin and Met-enkephalin were performed as described for SP using ${ }^{125} \mathrm{I}$-Tyr ${ }^{1}$-somatostatin and $\left[{ }^{3} \mathrm{H}\right] \mathrm{Met}$-enkephalin as radiolabeled ligands, respectively. In the radioimmunoassay for somatostatin, $8.4 \mathrm{pg}$ (or $5.1 \mathrm{fmol}$ ) was sufficient to displace $50 \%$ of the antibody-bound ${ }^{125} \mathrm{I}$-Tyr ${ }^{1}$-somatostatin. Antiserum to Met-enkephalin was the generous gift of Dr. James L. Meek (Laboratory of Preclinical Pharmacology, National Institute of Mental Health). Fifty percent displacement of antibody-bound $\left[{ }^{3} \mathrm{H}\right]$ Met-en- 
kephalin was attainable with $195 \mathrm{pg}$ (or $340 \mathrm{fmol}$ ) of Metenkephalin. The radioimmunoassay for $\beta$-NGF was performed as described previously (Schwartz and Costa, 1977 ) using mouse $\beta$-NGF as standard.

\section{Opioid receptor binding assay}

Preparation of spinal cord membrane suspensions. A crude membrane fraction from rat spinal cord was prepared by a modification of the procedure of Simon et al. (1973). Fresh spinal cord was homogenized in $10 \mathrm{ml}$ of

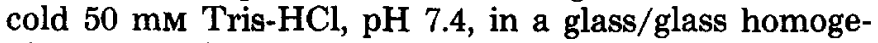
nizer. A portion of the crude homogenate was saved for protein determination and the remainder was centrifuged at $12,000 \times g$ for $20 \mathrm{~min}$ at $4^{\circ} \mathrm{C}$. The resulting pellet was resuspended in $10 \mathrm{ml}$ of ice cold glass-distilled water for $10 \mathrm{~min}$ before centrifuging as above. The final pellet was suspended in $100 \mathrm{~mm}$ Tris- $\mathrm{HCl}, \mathrm{pH} 7.4$, at a final protein concentration of $2 \mathrm{mg} / \mathrm{ml}$. Membranes were stored at $-20^{\circ} \mathrm{C}$ for 1 to 3 days prior to assay, conditions which control experiments indicate do not alter $\left[{ }^{3} \mathrm{H}\right]$ etorphine binding.

In some experiments, the membrane preparation procedure was altered to include steps which reputedly facilitate the dissociation of endogenous inhibitors of ligand binding (Simantov et al., 1976). Membranes were incubated either at $37^{\circ} \mathrm{C}$ for $15 \mathrm{~min}$ in Tris buffer or at $4^{\circ} \mathrm{C}$ for $60 \mathrm{~min}$ in Tris buffer containing $100 \mathrm{~mm} \mathrm{NaCl}$. Both procedures were followed by three centrifugations and resuspensions in sodium-free medium. Under the assay conditions used here (see below), neither modification of the membrane preparation procedure altered $\left[{ }^{3} \mathrm{H}\right]$ etorphine binding and the simplified procedure described above was adopted.

Incubation and assay procedure. Incubations with $\left[{ }^{3} \mathrm{H}\right]$ etorphine (New England Nuclear, $41.4 \mathrm{Ci} / \mathrm{mmol}$ ) were conducted at $37^{\circ} \mathrm{C}$ for 30 min with shaking in 500 $\mu \mathrm{l}$ of $100 \mathrm{~mm}$ Tris-HCl, $\mathrm{pH}$ 7.4. Spinal cord membranes ( $2 \mathrm{mg}$ of protein $/ \mathrm{ml}$ ) were preincubated for $5 \mathrm{~min}$ at $37^{\circ} \mathrm{C}$ prior to the addition of $\left[{ }^{3} \mathrm{H}\right]$ etorphine and levorphanol (Hoffman-La Roche, Nutley, NJ). Radioactivity bound to membranes was separated from free drug by rapid filtration through Whatman GF/C glass fiber filters. Filters were washed three times with $4 \mathrm{ml}$ of ice cold 100 mM Tris- $\mathrm{HCl}, \mathrm{pH}$ 7.4. Retained $\left[{ }^{3} \mathrm{H}\right]$ etorphine was measured by liquid scintillation counting at an efficiency of $49 \%$. Saturation binding curves were determined by incubating, in duplicate, a minimum of five concentrations of $\left.{ }^{3} \mathrm{H}\right]$ etorphine $(0.1$ to $3 \mathrm{mM})$ with the membrane preparation. Specific binding was determined by including duplicate tubes containing levorphanol $\left(10^{-6} \mathrm{M}\right)$ at each concentration of etorphine. The mean values of the duplicate determinations of each $\left[{ }^{3} \mathrm{H}\right]$ etorphine concentration were graphed as Scatchard plots. The association constant $\left(K_{D}\right)$ and receptor number $\left(B_{\mathrm{max}}\right)$ were determined by linear least squares analysis assuming a single class of sites.

\section{Animal treatment}

Adult female Sprague-Dawley rats were immunized with mouse 2.5 S NGF (Bocchini and Angeletti, 1969) as previously described (Gorin and Johnson, 1979). Such rats have been shown to produce antibodies which cross- react with rat NGF. Females selected as breeders in experiments reported here had been shown previously to produce severely affected litters as judged by the size of the sympathetic ganglia and the tyrosine hydroxylase activity in the superior cervical ganglia of the offspring at birth and by a marked decrease in the ability of littermates to transport ${ }^{125} \mathrm{I}-\mathrm{NGF}$ retrogradely to the sensory ganglia. The offspring used here were exposed to anti-NGF antibody in utero and in milk. Controls were age-matched offspring of mothers not immunized with NGF prior to or during pregnancy.

All rats were killed at maturity by decapitation. Tissues of interest were removed immediately, frozen on dry ice, and stored at $-70^{\circ} \mathrm{C}$ prior to extraction. In those instances in which both neuropeptide levels and opioid receptor binding were measured in the spinal cord, individual spinal cords were removed, placed on ice, and sliced into 2-mm cross-sectional slices. Alternate slices were pooled and saved either for immunoassay or radioreceptor assay.

Rat brains were sliced into $400-\mu \mathrm{m}$ sections in a cryostat at $-10^{\circ} \mathrm{C}$. Discrete nuclei were removed from frozen sections using a stainless steel dissecting needle as described by Palkovits (1973). Punches were stored at $-70^{\circ} \mathrm{C}$ prior to extraction.

\section{Protein determination}

Protein concentrations were determined by the method of Lowry et al. (1951) using BSA as standurd.

\section{Results}

Substance $P$ radioimmunoassay characteristics. The antiserum raised to a BSA conjugate of SP allows measurement of SP over the concentration range of 25 to 350 pM. Half-maximal displacement of ${ }^{125} \mathrm{I}$-Tyr ${ }^{8}$-substance $\mathrm{P}$ is attainable with $108 \mathrm{pM}$ nonradioactive SP or a concentration of $140 \mathrm{pg} / \mathrm{ml}$. Specificity studies with fragments of SP are summarized in Table I. The results indicate that the primary antigenic determinant is localized in the $\mathbf{N H}_{2}$-terminal portion of $\mathrm{SP}$ with amino acid residues 4 and 5 most directly implicated in antibody recognition. The COOH-terminal fragment, SP-(6-11), is ineffective in competing for antibody binding even at concentrations 5,000 times higher than the IC $_{50}$ for SP. SP biological activity has been shown to be connected specifically to the COOH-terminal hexapeptide (Bury and Mashford, 1976). Hence, the antibody recognition site differs from that of the SP receptor.

\section{TABLE I}

Specificity of SP antibody

The cross-reactivity of fragments of SP with the antiserum raised to a BSA conjugate of SP is shown. The values represent the means of two experiments in which each peptide fragment was tested at a minimum of six concentrations.

\begin{tabular}{lc}
\hline Peptide & Percent Cross-reactivity \\
\hline SP & 100 \\
SP-(3-11) & 76 \\
SP-(5-11) & 12.5 \\
SP-(6-11) & $<0.02$ \\
SP-(7-11) & $<0.02$ \\
\hline
\end{tabular}


Effect of NGF deprivation on neuropeptide levels in $D R G$, skin, and spinal cord. Exposure of rats to NGF antibody in utero and in milk dramatically alters the SP content of sensory ganglia (Table II). Treated rats killed in maturity showed a $56 \%$ depletion of SP in DRG compared with age-matched controls. SP levels in the target tissues innervated by these neurons also were reduced significantly in treated animals. Exposure to NGF antibodies reduced SP levels of the skin of the rat hind paw by $57 \%$, a depletion of comparable magnitude to that observed in DRG. Spinal cord levels of SP were reduced from $1.52 \mathrm{ng} / \mathrm{mg}$ of protein to $0.95 \mathrm{ng} / \mathrm{mg}$ or a total reduction of $37.5 \%$. The smaller proportional decrease in spinal cord reflects the diverse origin of SPcontaining neurons contributing to that pool. While a substantial portion of spinal cord SP is localized in terminals of primary afferents, a significant contribution also arises from the descending raphe-spinal pathway in which SP appears to coexist with serotonin (Chan-Palay et al., 1978; Hokfelt et al., 1978).

In addition to SP, somatostatin has been reported to be present in the small diameter cells of sensory ganglia which project to the dorsal horn of the spinal cord (Hokfelt et al., 1975). No effect of NGF deprivation was noted on levels of somatostatin-like immunoreactivity in either DRG or spinal cord when the data were expressed per milligram of protein (Table II). There was a $30 \%$ decrease (not statistically significant) in ganglion levels when the data were expressed as picograms per ganglia, in agreement with preliminary results from guinea pigs exposed to anti-NGF antiserum (J. P. Schwartz, M. Ross, S. Löfstrandh, P. D. Gorin, and E. M. Johnson, unpublished results). It is possible that the measurement of somatostatin in whole spinal cord obscured a significant change in the levels in the dorsal horn since a considerable portion of somatostatin in the spinal cord is associated with intrinsic neurons (Burnweit and Forssmann, 1979).

Effect of exposure to NGF antibodies on opiate receptor binding in rat spinal cord. A close correlation between SP and the opioid peptide, enkephalin, has been suggested in dorsal horn (Hokfelt et al., 1977). A number of lines of evidence indicate that opiate receptors may be localed presynaptically on SP primary afferents (La Motte et al., 1976; Jessell and Iversen, 1977; Hiller et al.,
1978; Mudge et al., 1979; Fields et al., 1980). Table III shows the results of Scatchard analysis of $\left[{ }^{3} \mathrm{H}\right]$ etorphine binding in spinal cord tissue of control and treated rats. Neither the maximal receptor binding capacity $\left(B_{\max }\right)$ nor the receptor affinity $\left(K_{D}\right)$ was altered by exposure to NGF antibody during development. The concentrations of $\left[{ }^{3} \mathrm{H}\right]$ etorphine chosen for the saturation analysis only allowed the investigation of the high affinity binding site of etorphine. The high affinity state of the receptor is believed to mediate the analgesic properties of opiates (Pasternak et al., 1980).

In a separate experiment, $\left[{ }^{3} \mathrm{H}\right]$ naloxone, an opiate antagonist, was used as the radiolabeled ligand instead of $\left[{ }^{3} \mathrm{H}\right]$ etorphine, a receptor agonist. Neither the receptor affinity nor the number of high affinity receptors in spinal cord differed in control and treated rats (control versus treated: $K_{D}=2.36 \mathrm{nM}$ versus $2.37 \mathrm{nM} ; B_{\max }=5.8 \mathrm{pmol} /$ gm, wet weight, versus $7.8 \mathrm{pmol} / \mathrm{gm}$, wet weight) when this alternative ligand was used. Enkephalin-like immunoreactivity in spinal cord was also unaltered by exposure to NGF antibodies (control, $0.75 \pm 0.05(n=5)$; treated, $0.68 \pm 0.06(n=5)$ ng of enkephalin-like immunoactivity/ mg of protein).

$S P$ levels in central neurons of control and treated rats. Measurement of SP in discrete brain regions (Table IV) confirmed the previous findings of a wide and uneven distribution of this neuropeptide in rat brain (Brownstein et al., 1976). Highest concentrations were noted in sub-

\section{TABLE III}

Opioid receptor binding in rat spinal cord

Opiate receptor binding was determined in spinal cords from control rats and from rats exposed to anti-NGF antibodies in utero and in milk. Opioid binding was determined by incubating a minimum of five concentrations of the opioid agonist, $\left[{ }^{3} \mathrm{H}\right]$ etorphine, with spinal cord membranes. The estimated receptor affinity $\left(K_{D}\right)$ and maximal receptor binding capacity $\left(B_{\max }\right)$ were determined from Scatchard plots. Over the concentration range of the radioligand chosen, Scatchard plots were linear and $K_{D}$ and $B_{\max }$ values were determined by linear least squares analysis. The numbers in parentheses indicate number of animals tested.

\begin{tabular}{ccc}
\hline$\left[{ }^{3} \mathrm{H}\right]$ Etorphine & $K_{D}$ & $B_{\max }$ \\
& $n_{M}$ & $f m o l / m g$ protein \\
Control (7) & $0.21 \pm 0.02$ & $52 \pm 4$ \\
Treated (9) & $0.21 \pm 0.01$ & $46 \pm 3$ \\
\hline
\end{tabular}

TABLE II

Effect of NGF deprivation on neuropeptide levels in DRG, spinal cord, and skin

SP and somatostatin levels were determined by specific radioimmunoassays for each substance in DRG, spinal cord, and skin from control rats and rats exposed to anti-NGF antibodies in utero and in milk. The values represent the means \pm SEM. The levels in individual animal tissues were estimated from duplicate determinations. The numbers in parentheses indicate the number of animals included in each group. Significance was tested by the Student's $t$ test.

\begin{tabular}{|c|c|c|c|c|}
\hline \multirow{2}{*}{ Tissue } & \multicolumn{2}{|c|}{$\mathbf{S P}$} & \multicolumn{2}{|c|}{ Somatostatin } \\
\hline & Control & Treated & Control & Treated \\
\hline & \multicolumn{2}{|c|}{$p g / m g$ prulein } & \multicolumn{2}{|c|}{$p g / m g$ protein } \\
\hline DRG & $124 \pm 9$ & $55 \pm 4^{a}$ & $25 \pm 2$ & $21 \pm 2$ \\
\hline Spinal cord & $1518 \pm 161$ & $946 \pm 79^{b}$ & $1166 \pm 125$ & $1210 \pm 57$ \\
\hline Skin & $1.59 \pm 0.19$ & $0.68 \pm 0.08^{c}$ & N.D. ${ }^{d}$ & N.D. \\
\hline
\end{tabular}

${ }^{a} p<0.001$.

${ }^{b} p<0.01$.

${ }^{c} p<0.05$.

${ }^{d}$ N.D., not determined. 
TABLE IV

Effect of NGF deprivation on SP levels in brain

The levels of SP in discrete areas of rat brain were compared in animals exposed to anti-NGF antibodies during development (treated) and in controls. The values represent the means \pm SEM determined from duplicate determinations in the radioimmunoassay for SP. The numbers in parentheses represent the number of animals included in the study.

\begin{tabular}{llc}
\hline \multirow{2}{*}{ Brain Region } & \multicolumn{2}{c}{ SP } \\
\cline { 2 - 3 } & \multicolumn{1}{c}{ Control } & Treated \\
\hline \multirow{2}{*}{ Nucleus accumbens } & \multicolumn{2}{c}{$n g$ protein } \\
Caudate & $1.29 \pm 0.18(10)$ & $1.01 \pm 0.16(9)$ \\
Globus pallidus & $0.60 \pm 0.05(10)$ & $0.67 \pm 0.07(9)$ \\
Habenula & $0.95 \pm 0.16(10)$ & $0.78 \pm 0.08(9)$ \\
Amygdaia & $0.57 \pm 0.06(10)$ & $0.69 \pm 0.06(9)$ \\
Intrapeduncular nucleus & $0.51 \pm 0.06(10)$ & $0.50 \pm 0.04(9)$ \\
Substantia nigra & $2.92 \pm 0.49(9)$ & $2.62 \pm 0.34(8)$ \\
Dorsal raphe & $4.34 \pm 0.88(10)$ & $4.20 \pm 0.42(9)$ \\
Medial raphe & $3.00 \pm 0.32(5)$ & $2.92 \pm 0.33(5)$ \\
\hline
\end{tabular}

TABLE V

Effect of exposure to anti-NGF antibody on SP levels in peripheral tissues

SP levels in peripheral tissues were established by radioimmunoassay. The results represent the means \pm SEM with the number of samples tested indicated in parentheses. "Treated" implies exposure to anti-NGF antibodies both in utero and in milk.

\begin{tabular}{|c|c|c|}
\hline \multirow{2}{*}{ Tissue } & \multicolumn{2}{|c|}{ SP } \\
\hline & Control & Treated \\
\hline & \multicolumn{2}{|c|}{$p g / m g$ protein } \\
\hline Retina & $335 \pm 42(5)$ & $314 \pm 20$ \\
\hline Submaxillary gland & $100 \pm 10(10)$ & $102 \pm 8$ \\
\hline Ileum & $359 \pm 22$ & $343 \pm 27$ \\
\hline Adrenal gland & $7.6 \pm 0.2(5)$ & $5.6 \pm 0.5^{a}(4)$ \\
\hline
\end{tabular}

${ }^{a} p<0.01$ as determined by the Student's $t$ test.

stantia nigra, dorsal raphe, and intrapeduncular nucleus. However, no difference in SP levels was noted between control and treated animals in any of the nine brain regions studied.

Dependence of SP levels in selected peripheral tissues on NGF. SP innervation of the adrenal (Linnoila et al., 1980) and ileum (Schultzberg et al., 1980; Costa et al., 1981) has been demonstrated by immunofluorescence. In addition, SP has been localized in amacrine cells of the retina (Karten and Brecha, 1980) by immunohistochemistry and in the submaxillary gland by radioimmunoassay (Robinson et al., 1980). When the SP content of these tissues was compared in treated and control rats, levels in retina, submaxillary gland, and ileum were unaffected by the presence of anti-NGF antibody during development (Table V). Interestingly, the levels of NGF in submaxillary glands, as determined by a specific radioimmunoassay, were also unchanged (control $(n=5), 3.44$ \pm 0.33 ; treated $(n=5), 3.30 \pm 0.35 \mathrm{ng} / \mathrm{mg}$ of protein). However, the SP content of adrenal glands was decreased significantly in treated animals versus controls.

\section{Discussion}

A physiological role for NGF in the developing nervous system has been established most convincingly by mon- itoring the effects of in vivo NGF deprivation. Such deprivation currently can be achieved through the autoimmune approach described by Gorin and Johnson (1979); other possible approaches to NGF depletion are hampered by the lack of a specific NGF antagonist and by the lack of definitive information on the tissue sources of NGF. The validity of the autoimmune approach has been strengthened by recent evidence that the effects of anti-NGF antibodies arise directly from the neutralization of endogenous NGF rather than from a complementmediated cytolysis (Ennis et al., 1979; Goedert et al., 1980).

The autoimmune approach has provided strong evidence for a requisite function for NGF in sensory neuron development (Gorin and Johnson, 1979; Johnson et al., 1980). In utero exposure to anti-NGF antibody results in a $70 \%$ depletion in cell number in the sensory ganglia in rats. The experiments reported here suggest that part of that depletion can be attributed to the loss of SP-containing neurons. SP is contained within small diameter cells of the sensory ganglia (Chan-Palay and Palay, 1977a, b; Hokfelt et al., 1977), the cell population which size frequency histograms indicate is affected most severely by anti-NGF antibody (Johnson et al., 1980). It is noteworthy, however, that the depletion of SP observed in ganglia (and in the target tissue skin) is incomplete, with 43 to $44 \%$ of the control levels of SP persisting in treated rats. An incomplete destruction of SP neurons in the rat is inferred from the fact that the rats appear normally responsive to painful stimuli. This is in contrast to guinea pigs born to anti-NGF producing mothers which are insensitive to painful stimuli (e.g., capsaicin). As expected, preliminary experiments indicate much greater decreases in SP in DRG and spinal cord in these animals (J. P. Schwartz, M. Ross, S. Löfstrandh, P. D. Gorin, and E. M. Johnson, unpublished results). This incomplete destruction of SP neurons may be indicative of an insufficient titer of NGF antibody or of insufficient access of maternal antibodies to the fetus during critical stages of development. Alternatively, there may exist more than one population of SP neurons in DRG which subserve different sensory functions and which possess different sensitivities to NGF.

Somatostatin levels in DRG, expressed per milligram of protein, were unaffected by prenatal and postnatal exposure to anti-NGF antiserum in rats. However, preliminary results show a significant change in somatostatin levels in affected guinea pig DRG, and again, the difference may reflect the greater sensitivity of the guinea pigs to exposure to anti-NGF. Direct evidence for the sensitivity of somatostatin neurons to NGF comes from tissue culture work (Mudge, 1979). However, differences in the growth factor responsiveness of somatostatin- and SP-containing neurons have been noted previously. In primary culture, ganglionic non-neuronal cells, presumably through the release of a trophic factor other than NGF (Lindsay, 1980), have been shown to increase the level of somatostatin relative to SP (Mudge, 1979).

Central SP neurons were unaffected by exposure to anti-NGF antiserum in utero and in milk. Such refractoriness of central neurons to NGF is in agreement with previous observations on noradrenergic neurons in culture. While peripheral sympathetic neurons are exquis- 
itely sensitive to NGF both prenatally and postnatally, embryonic adrenergic neurons from the locus coeruleus or cortex were not responsive to NGF (or anti-NGF antibody) in cell culture (Olson et al., 1979). However, it is again possible that the failure to detect an effect of anti-NGF antibodies on central SP neurons is the result of inadequate in utero exposure. Confirmation of this and other negative findings reported here should be sought in guinea pigs, a species in which larger quantities of maternal antibodies are transferred prenatally (Brambell, 1970).

The decreased level of immunoreactive SP observed in adrenal glands is noteworthy. SP innervation of the adrenal has been established by immunohistochemistry (Linnoila et al., 1980). A physiological role for this peptide in inhibiting the acetylcholine-stimulated release of catecholamines from chromaffin cells has been suggested (Livett et al., 1979). However, little is known of these neurons and their cell bodies have yet to be identified.

No decrease in opiate receptor density was detected in rats exposed to anti-NGF antibody during development despite a substantial reduction in SP levels in spinal cord. Since the decreased levels of SP presumably reflect cell death (Johnson et al., 1980), this result contrasts markedly with observations suggesting that opiate receptors are located presynaptically on SP-containing primary afferents. The presynaptic localization of opiate receptors on sensory terminals has been inferred from the loss of spinal cord opiate receptors observed after dorsal rhizotomy (La Motte et al., 1976; Jessell et al., 1979) and from the depletion of spinal cord opiate receptors noted after treatment of newborn rats with capsaicin (Gamse et al., 1979; Nagy et al., 1980). The ability of opiates to inhibit stimulated SP release in spinal cord in vivo (Yaksh et al., 1980) lends support to a presynaptic localization of opiate receptors as do in vitro experiments which show an inhibitory action of opiates on SP release from rat trigeminal nucleus (Jessell and Iversen, 1977) and DRG neurons (Mudge et al., 1979).

While the negative findings reported here apparently contradict the presynaptic localization of opiate receptors on SP sensory terminals, it is possible that the use of whole spinal cord in the determination of opiate receptor number obscured a significant difference in a relatively small population of receptors localized on primary afferents (Herkenham and Pert, 1980). Additional experiments using tissue derived only from dorsal horn may clarify this issue. It is noteworthy, however, that electron microscopic studies on the synaptic relationships of SP axons in spinal cord have failed to produce morphological support for the presynaptic localization of opiate receptors on SP primary afferents (Ralston and Ralston, 1979; Barber et al., 1979). Immunohistochemical techniques show SP primary afferents largely in lamina I of the dorsal horn. Primary afferents in that region do not appear to participate in axoaxonal contact and, hence, are unlikely to be subject to presynaptic inhibition. The electron microscopic examination of Met-enkephalincontaining neurons in the spinal cord also has failed to reveal a direct interaction between primary afferents and enkephalinergic neurons (Hunt et al., 1980).

The autoimmune model has provided strong evidence that, during early development, substance P-containing sensory neurons are dependent on NGF or a closely related cross-reacting substance. Subsequent experiments with this model can be expected to define more precisely the critical stage during which NGF is required for survival of these neurons. A re-examination of the role of NGF in the postnatal development of SP-containing sensory neurons (Kessler and Black, 1980, 1981; Otten et al., 1980) and an evaluation of the importance of NGF in the maintenance of mature sensory neurons should be undertaken also. Finally, the ability of anti-NGF antibodies to impair the development of SP-containing sensory neurons suggests that the autoimmune model will provide an important new approach to investigating the role of SP in pain perception.

\section{References}

Andres, K. H. (1961) Untersuchungen uber den Feinbau von Spinalganglien. Z. Zellforsch. Mikrosk. Anat. 55: 1-48.

Barber, R. P., J. E. Vaughn, J. R. Slemmon, P. M. Salvaterra, E. Roberts, and S. E. Leeman (1979) The origin, distribution, and synaptic relationships of substance $P$ axons in rat spinal cord. J. Comp. Neurol. 184: 331-351.

Bocchini, F., and P. U. Angeletti (1969) The nerve growth factor: Purification as a 30,000 molecular weight protein. Proc. Natl. Acad. Sci. U. S. A. 64: 787-794.

Brambell, F. W. R. (1970) Frontiers of Biology: The Transmission of Passive Immunity from Mother to Young, Vol. 18, pp. 324-365, Elsevier, New York.

Brownstein, M., E. A. Mroz, J. S. Kizer, M. Palkovits, and S. E. Leeman (1976) Regional distribution of substance $P$ in the brain of the rat. Brain Res. 116: 299-305.

Burnweit, C., and W. G. Forssmann (1979) Somatostatinergic nerves in the cervical spinal cord of the monkey. Cell Tissue Res. 200: 83-90.

Bury, R. W., and M. L. Mashford (1976) Biological activity of C-terminal partial sequences of substance P. J. Med. Chem. 19: 854-856.

Chan-Palay, V., and S. L. Palay (1977a) Immunocytochemical identification of substance $P$ cells and their processes in rat sensory ganglia and their terminals in the spinal cord: Light microscopic studies. Proc. Natl. Acad. Sci. U. S. A. 74: 35973601 .

Chan-Palay, V., and S. L. Palay (1977b) Ultrastructural identification of substance $\mathrm{P}$ cells and their processes in rat sensory ganglia and their terminals in the spinal cord by immunocytochemistry. Proc. Natl. Acad. Sci. U. S. A. 74: 4050-4054.

Chan-Palay, V., G. Jonsson, and S. L. Palay (1978) Serotonin and substance $P$ coexist in neurons of the rat's central nervous system. Proc. Natl. Acad. Sci. U. S. A. 75: 1582-1586.

Chang, M. M., and S. E. Leeman (1970) Isolation of a sialogogic peptide from bovine hypothalamic tissue and its characterization as substance P. J. Biol. Chem. 245: 4784-4790.

Costa, M., J. B. Furness, I. J. Llewellyn-Smith, and A. C. Cuello (1981) Projections of substance P-containing neurons within the guinea pig small intestine. Neuroscience 6: 411-424.

Ennis, M., F. L. Pearce, and C. A. Vernon (1979) Some studies on the mechanism of action of antibodies to nerve growth factor. Neuroscience 4: 1391-1398.

Fields, H. L., P. C. Emson, B. K. Leigh, R. F. Gilbert, and L. L. Iversen (1980) Multiple opiate receptor sites on primary afferent fibres. Nature 284: 351-353.

Gamse, R., P. Holzer, and F. Lembeck (1979) Indirect evidence for presynaptic location of opiate receptors on chemosensitive primary sensory neurons. Naunyn Schmiedebergs Arch. Pharmacol. 308: 281-285.

Goedert, M., U. Otten, Th. Schafer, M. Schwab, and H. Thoe- 
nen (1980) Immunosympathectomy: Lack of evidence for a complement-mediated cytotoxic mechanism. Brain Res. 201: 399-409.

Goodfriend, T. L., L. Levine, and G. D. Fasman (1964) Antibodies to bradykinin and angiotensin: $A$ use of carbodiimides in immunology. Science 144: 1344-1346.

Gorin, P. D., and E. M. Johnson (1979) Experimental autoimmune model of nerve growth factor deprivation: Effects on developing peripheral sympathetic and sensory neurons. Proc. Natl. Acad. Sci. U. S. A. 76: 5382-5386.

Gorin, P. D., and E. M. Johnson (1980) Effects of long-term nerve growth factor deprivation on the nervous system of the adult rat: An experimental autoimmune approach. Brain Res. 198: $27-42$.

Henry, J. L. (1976) Effects of substance $P$ on functionally identified units in cat spinal cord. Brain Res. 114: 439-451.

Herkenham, M., and C. B. Pert (1980) In vitro autoradiography of opiate receptors in rat brain suggests loci of opiatergic pathways. Proc. Natl. Acad. Sci. U. S. A. 77: 5532-5536.

Hiller, J. M., E. J. Simon, S. M. Crain, and E. R. Peterson (1978) Opiate receptors in cultures of fetal mouse dorsal root ganglia (DRG) and spinal cord: Predominance in DRG neurites. Brain Res. 145: 396-400.

Hokfelt, T., R. Elde, O. Johansson, R. Luft, and A. Arimura (1975) Immunohistochemical evidence for the presence of somatostatin, a powerful inhibitory peptide, in some primary sensory neurons. Neurosci. Lett. 1: 231-235.

Hokfelt, T., A. Ljungdahl, L. Terenius, R. Elde, and G. Nilsson (1977) Immunohistochemical analysis of peptide pathways possibly related to pain and analgesia: Enkephalin and substance P. Proc. Natl. Acad. Sci. U. S. A. 74: 3081-3085.

Hokfelt, T., A. Ljungdahl, H. Steinbusch, A. Verhofstad, G. Nilsson, N. E. Bordin, B. Pernow, and M. Goldstein (1978) Immunohistochemical evidence of substance P-like immunoreactivity in some 5-hydroxytryptamine-containing neurons in the rat central nervous system. Neuroscience 3: 517538.

Hunt, S. P., J. S. Kelly, and P. C. Emson (1980) The electron microscopic localization of methionine-enkephalin within the superficial layers (I and II) of the spinal cord. Neuroscience 5: $1871-1890$.

Hunter, W. M., and F. C. Greenwood (1962) Preparation of iodine-131 labelled human growth hormone of high specific activity. Nature 194: 495-496.

Jessell, T. M., and L. L. Iversen (1977) Opiate analgesics inhibit substance $P$ release from rat trigeminal nucleus. Nature 268 : 549-551.

Jessell, T. M., A. Tsunoo, I. Kanazawa, and M. Otsuka (1979) Substance $\mathrm{P}$ depletion in the dorsal horn of rat spinal cord after section of the peripheral processes of primary sensory neurons. Brain Res. 168: 247-259.

Johnson, E. M., Jr., P. D. Gorin, L. D. Brandeis, and J. Pearson (1980) Dorsal root ganglion neurons are destroyed by exposure in utero to maternal antibody to nerve growth factor. Science 210: 916-918.

Karten, H. J., and N. Brecha (1980) Localization of substance $P$ immunoreactivity in amacrine cells of the retina. Nature 283: 87-88.

Katayama, Y., R. A. North, and J. T. Williams (1979) The action of substance $P$ on neurons of the myenteric plexus of the guinea-pig small intestine. Proc. R. Soc. Lond. (Biol.) 206: 191-208.

Kessler, J. A., and I. B. Black (1980) Nerve growth factor stimulates the development of substance $\mathrm{P}$ in sensory ganglia. Proc. Natl. Acad. Sci. U. S. A. 77: 649-652.

Kessler, J. A., and I. B. Black (1981) Nerve growth factor stimulates development of substance $P$ in the embryonic spinal cord. Brain Res. 208: 135-145.
La Motte, C., C. B. Pert, and S. H. Snyder (1976) Opiate receptor binding in primate spinal cord: Distribution and changes after dorsal root section. Brain Res. 112: 407-412.

Levi-Montalcini, R., and P. U. Angeletti (1968) Nerve growth factor. Physiol. Rev. 48: 534-569.

Levi-Montalcini, R., and B. Booker (1960) Destruction of the sympathetic ganglia in mammals by an antiserum to the nerve growth factor. Proc. Natl. Acad. Sci. U. S. A. 42: 384391.

Lindsay, R. M. (1980) Adult rat brain astrocytes support survival of both NGF-dependent and NGF-insensitive neurones. Nature 282: 80-82.

Linnoila, R. I., R. P. DiAugustine, A. Hervonen, and R. J. Miller (1980) Distribution of [met $\left.{ }^{5}\right]$ - and $\left[\mathrm{leu}^{5}\right]$-enkephalin-, vasoactive intestinal peptide- and substance P-like immunoreactitives in human adrenal glands. Neuroscience 5: 2247-2259.

Livett, B. G., V. Kozonsek, F. Mizobe, and D. M. Dean (1979) Substance $P$ inhibits nicotinic activation of chromaffin cells. Nature 278: 256-257.

Lowry, O. H., N. J. Rosebrough, A. L. Farr, and R. J. Randall (1951) Protein measurement with the Folin phenol reagent. J. Biol. Chem. 193: 265-275.

Morita, K., A. R. North, and Y. Katayama (1980) Evidence that substance $P$ is a neurotransmitter in the myenteric plexus. Nature 287: 151-152.

Mudge, A. W. (1979) Somatostatin and substance P levels in cultured sensory neurons are influenced by environmental factors. Soc. Neurosci. Abstr. 5: 534.

Mudge, A. W., S. E. Leeman, and G. D. Fischbach (1979) Enkephalin inhibits release of substance $P$ from sensory neurons in culture and decreases action potential duration. Proc. Natl. Acad. Sci. U. S. A. 76: 526-530.

Nagy, J. I., S. R. Vincent, W. A. Staines, H. C. Fibiger, T. D. Reisine, and H. I. Yamamura (1980) Neurotoxic action of capsaicin on spinal substance P neurons. Brain Res. 186: 435444.

Olson, L., T. Ebendal, and A. Seiger (1979) NGF and anti-NGF: Evidence against effects on fiber growth in locus coeruleus from cultures of perinatal CNS tissues. Dev. Neurosci. 2 : 160-176.

Otsuka, M., and S. Konishi (1975) Substance P and excitatory transmitter of primary sensory neurons. Cold Spring Harbor Symp. Quant. Biol. 40: 135-143.

Otten, U., M. Goedert, N. Mayer, and F. Lembeck (1980) Requirement of nerve growth factor for development of substance P-containing sensory neurones. Nature 287: 158-159.

Palkovits, M. (1973) Isolated removal of hypothalamic or other brain nuclei of the rat. Brain Res. 59: 449-450.

Pasternak, G. W., A. Zhang, and L. Tecott (1980) Developmental differences between high and low affinity opiate binding sites: Their relationship to analgesia and respiratory depression. Life Sci. 27: 1185-1190.

Ralston, H. J., III, and D. D. Ralston (1979) The distribution of dorsal root axons in Laminae I, II and III of the macaque spinal cord: A quantitative electron microscope study. J. Comp. Neurol. 184: 643-684.

Randic, M., and V. Miletic (1977) Effect of substance $P$ in cat dorsal horn neurones activated by noxious stimuli. Brain Res. 128: 164-169.

Robinson, S. E., J. P. Schwartz, and E. Costa (1980) Substance $P$ in the superior cervical ganglion and the submaxillary gland of the rat. Brain Res. 182: 11-17.

Schultzberg, M., T. Hokfelt, G. Nilsson, L. Terenius, J. F. Rehfeld, M. Brown, R. Elde, M. Goldstein, and S. Said (1980) Distribution of peptide and catecholamine-containing neurons in the gastro-intestinal tract of rat and guinea pig. Immunohistochemical studies with antisera to substance $P$, vasoactive intestinal peptide, enkephalins, somatostatin, gas- 
trin/cholecystokinin, neurotensin and dopamine $\beta$-hydroxylase. Neuroscience 5: 689-744.

Schwartz, J. P., and E. Costa (1977) Regulation of nerve growth factor content in $\mathrm{C} 6$ glioma cells by $\beta$-adrenergic receptor stimulation. Naunyn Schmiedebergs Arch. Pharmacol. 300: $123-129$.

Schwartz, J. P., and E. Costa (1979) Nerve growth factormediated increase of the substance $P$ content of chick embryo dorsal root ganglia. Brain Res. 170: 198-202.

Simantov, R., A. M. Snowman, and S. H. Snyder (1976) Temperature and ionic influences on opiate receptor binding. Mol. Pharmacol. 12: 977-986.
Simon, E. J., J. M. Hiller, and I. Edelman (1973) Stereospecific binding of the potent narcotic analgesic $\left[{ }^{3} \mathrm{H}\right]$ etorphine to rat brain homogenate. Proc. Natl. Acad. Sci. U. S. A. 70: 19471949.

Stoeckel, K., M. Schwab, and H. Thoenen (1975) Specificity of retrograde transport of nerve growth factor (NGF) in sensory neurons: A biochemical and morphological study. Brain Res. 89: 1-14.

Yaksh, T. L., T. M. Jessell, R. Gamse, A. W. Mudge, and S. E. Leeman (1980) Intrathecal morphine inhibits substance $P$ release from mammalian spinal cord in vivo. Nature 286: $155-157$. 